\title{
Conceptualizing Small and Medium Scale Enterprises; It's Implications to the Economic Growth of Nigeria, 1999-2016
}

\author{
MICAH Ezekiel Elton Micheal ${ }^{1}$, Kassahvirginia ${ }^{2}$, Ruth A. Andah ${ }^{3}$ \\ ${ }^{1}$ Departments of Business Administration, Faculty of Administration, Nasarawa State University Keffi \\ Nigeria \\ ${ }^{2}$ Lecturer, Department Of Business Administration, Kaduna State University (KASU), Nigeria \\ ${ }^{3}$ Lecturer, Department Of Business Administration, Faculty of Administration, Nasarawa State \\ University Keffi Nigeria
}

\begin{abstract}
The paper set to examine the impact of small and medium enterprises on the economic growth of Nigeria. This was discussed based on the impact of micro finance policy in Nigeria. This study assesses the financing options available to Small and Medium Scale Enterprises (SMEs) in Nigeria. Therefore, the paper concludes that the government should focus more on promoting small and medium scale enterprises (SMEs) in Nigeria by giving more microfinance banks opportunity to operate freely and give loan to the SMEs in Nigeria. The major recommendation is that Capacity building and sensitization programmes for all registered SMEs should be put in place by government to enlighten them on the benefits of good risk management and insurance of their businesses. Both the government and the banking sector should mutually agree on a credit guaranteed scheme strategy that will incorporate a risk-sharing arrangement as a way of encouraging the banks to channel funds to the SMEs sub sector for their growth and development which would translate into the national economic growth and sustainable economic development of Nigeria.
\end{abstract}

Keywords: Small and Medium Scale Enterprises, Economic Growth of Nigeria

\section{INTRODUCTION}

Few are of the opinion that a vibrant Small and Medium Enterprise (SME) sector can form the bedrock on which all economic activity is built, and that SMEs can be the mainstay of an economy, particularly in terms of employment. In many emerging markets the SME sector is one of the principal driving forces for economic growth and job creation. And this holds particularly true for many countries in Africa where SMEs and the informal sector represent over $90 \%$ of businesses, contribute to over 50\% of GDP, and account for about $63 \%$ of employment in low income countries. However, inadequate access to financing continues to be one of the most significant impediments to creation, survival, and growth of SMEs in Africa. Providing finance to SMEs in Africa is a complicated affair. Adding the criteria of sustainability in assessment of such enterprises further increases the challenge. Nevertheless, few innovative business models have emerged that show to the larger investment community that it is clearly possible to create value for the environment as well as larger development goals without sacrificing financial returns. However, there is no denying the fact that the sector is a sine qua non in ensuring the attainment of the goals of the federal government's National Economic Empowerment Development Strategy (NEEDS) aside from the SMES possessing the potential for stimulating industrial growth, which are mainly poverty reduction, employment generation, wealth creation and value orientation. Although, some set of factors hinders the performance of SMEs for maximum contribution to the economy. In this regard, Sangosanya (2010) identified ten key factors and variables have been identified to influence SMES'S failure in Nigeria. These include disasters, competition, infrastructure, taxes, accounting, management, marketing, economic, planning and finance. In Nigeria, poor economic conditions, which also implies poor finance and inadequate infrastructure, have been identified as the most crucial factors (Ihua, 2009). This position is corroborated by other studies which identified financial support as one of the main factors responsible for small business failures in Nigeria (Abereijo\& Fayomi, 2015). The problem of inadequate finance affects SMES effective performance of other ancillary functions such as marketing, as they are unable to offer competitive credit terms to distributors, delay or cut in 
production resulting from raw materials shortage thus causing sometimes sharp drop in sales volume. These problems are compounded by the unwillingness of entrepreneurs of SMES enterprises to share ownership with individual or institutional fund providers in order to raise needed equity capital. This article highlights tie systematic dwindling growth of small and medium scale enterprises in Nigeria between 1999 and 2016.

\section{BACKGROUND TO THE STUDY}

Evidences have shown that prior to the late 19th century, cottage industries, and mostly small and medium scale businesses controlled the economy of world giants like Europe and America. The industrial revolution changed the status quo and introduced mass production. The Small and Medium Scale Enterprises (SMEs) development facilitates the mobilization of human and capital resources towards economic development, in general, and the rural sector, in particular. They have been identified as a vehicle for employment generation and providing opportunities for entrepreneurial sourcing, training, development and empowerment. Developing nations such as Nigeria characterized as low income earners by the World Bank, value small and medium scale enterprises (SMEs) for several reasons. Viewed in static terms, the main argument is that SMEs, on average achieve decent levels of productivity especially of capital and factors taken together (that is, total productivity factor) while also generating relatively large amount of socio-economic development. In dynamic terms, the SMEs sector is viewed as being populated by firms most of which have considerable growth potential. SMEs in developing countries achieve productivity increases to a great extent simply by borrowing from the shelf of technologies available in the world (Christopoulos and Tsionas, 2014).

Nigeria remains a country with very high potential but an equally high inertia to develop. The country is blessed with abundant supply of enormous human, agricultural, petroleum, gas, and large untapped solid mineral resources (Obadan, 2003). Since her independence from British rule in 1960, the country has gone through decades of political instability and this has brought with it a climate of social tension and an unpredictable market for business. The successive forceful takeover of government by the use of military coup and the indigenization policy of the late 70's has put off investors who hitherto saw the country as a large and growing market. Due to the nature of these governments, there is perceived corruption, policy instability, poor infrastructural development and lack of accountability of public funds. For these reasons, the World Bank described Nigeria as a paradox (World Bank, 1996). This is also true for most Sub-Saharan African countries as industrial production has declined or stagnated over the past decades (Lall, 1992).

According to Mambula (1997), since its independence, the Nigerian government has been spending an immense amount of money obtained from external funding institutions for entrepreneurial and small business development programs, which have generally yielded poor results. Unfortunately these funds hardly reach the desired business because they may be lost to bureaucratic bottle necks and end up in accounts of public office holders. Despite these setbacks, the role of small business owned by middle class Nigerians, set up by individual savings, gifts and loans and sometimes sustained by profit cannot be ignored. According to Asmelash (2002), countries that have made economic breakthroughs in the last two decades demonstrated beyond doubt that the development of entrepreneurship has been the sine qua non of economic growth and development. According to Asmelah (2002), the significant role SMEs play in development is acknowledged world over. He cited the work of Schell, (1996), who noted that in developed countries such as the USA, where big corporations are dominant, SMEs still play enormous role in the country's economy.

Also, according to the report of the Indian working group on science and technology for Small- and medium-scale enterprises, SMEs occupy an important and strategic place in economic growth and equitable development in all countries. Constituting as high as $90 \%$ of enterprises in most countries worldwide, SMEs are the driving force behind a large number of innovations and contribute to the growth of the national economy through employment creation, investments and exports. Owing to the success of the Asian tigers, interest is running high globally particularly in developing countries that are in the rat race to meet up and reduce the economic and development gap. Chinese and foreign experts estimated that SMEs are now responsible for about $60 \%$ of China's industrial output and employ about $75 \%$ of the workforce in China's cities and towns (Schell, 1996). These SMEs creates jobs for workers who have been laid off from state-owned enterprises due to the steady transition from communism to a market based economy. 
According to Cook and Nisxon (2000), interest in the role of small and medium-sized enterprises (SMEs) in the development process continues to be in the forefront of policy debates in developing countries. Owing to the relevance of SME's, in 2006, the government of Taiwan launched a \$61 million "branding" initiative, which was aimed to push the economy from being production-based to knowledge-based. According to the report in EE Times Asia in August 2006, the so-called "Branding Taiwan Plan" is a seven-year program designed to help promising small-to-medium enterprises (SMEs) in developing their own brand, according to the Taiwanese government. This was initiated with the full consciousness of the ability of SMEs to drive the economy particularly in the medium term. Small businesses employ 72,000,000 people (Asmelash, 2002). More than 90 per cent of the industries in Indonesia, Philippines, Thailand, Hong Kong, Japan, Korea, India and Sri Lanka are small enterprises (Fadahunsi and Daodu 1997).

A 2004 survey conducted by the Manufacturers Association of Nigeria (MAN) revealed that only about ten percent (10\%) of industries run by its members are fully operational. Essentially, this means that 90 percent of the industries are either ailing or have closed down. Given the fact that manufacturing industries are well-known catalysts for real growth and development of any nation, this reality clearly portends a great danger for the Nigerian economy. The acting director-general of the association, Mr. Jide Mike, who disclosed this fact, attributed the cause of this sorry state to such factors as poor infrastructure, multiple taxes imposed on manufacturers in Lagos state by all tiers of government and the difficulty in accessing finance. He noted, "The debris of dilapidated manufacturing concerns across the country is the outcome of years of harsh operating conditions". Jide (2012), also remarked, "In addition to policy somersault, funding remains a challenge to all stakeholders in the manufacturing sector, the several palliatives, including the Small and Medium Industries Equity Investment Scheme (SMIEIS) and other sector-specific incentives notwithstanding". He added, "In summary, 30 percent of industries in Nigeria have closed down. About 60 percent are ailing companies and only 10 percent operate at sustainable level". The acting director-general of MAN (manufacturing association of Nigeria) emphasized that low capacity utilization has undermined the competitiveness of manufacturing industries, whose fortunes have been worsened by the impact of globalization. He recalled that at Nigeria's independence in 1960, the manufacturing sector's contribution to national Gross Domestic Product (GDP) was 3.8 percent and that despite the discovery of oil, manufacturing contributed as much as 9.9 percent to the GDP from 1975 to 1981 when capacity building was above 70 percent. Jide (2012), however regretted that the story is different today as the manufacturing sector is back at the independence level as it contributed a mere 4.7 percent to GDP in 2003 while industrial capacity utilization dropped to a paltry 48.8 percent in 2003.

The above is indeed not encouraging as it is representative of the fate of the manufacturing sub-sector of the SMEs. It was said that the large manufacturing companies are even better off given that those of them, which have international affiliation do get succor and support from their parent companies or technical partners overseas. The support and services the multinationals get from their parent companies could be driven by the profit repatriation, expansion of their overseas market and other motivations but overall, the Nigerian economy benefits if only through employment generation. President Olusegun Obasanjo in his address on March 01, 2002 at the commissioning of the headquarters of SMEDAN (The Small and Medium Enterprises Development Agency of Nigeria) in Abuja also noted that there was a great disconnection between the SMEs and the large companies in Nigeria, pointing out that the multinational companies dominated business in the country even in the area of finished products. Because of these and other debilitating problems, only about 10 percent of SMEs in Nigeria are into manufacturing.

\section{Conceptual Review}

\subsection{Small and Medium Scale Enterprises (SMEs)}

For decades, the Small and Medium business have been found to constitute the very foundation upon which the large businesses were built. However, small and medium have been identified differently by various individuals and organization such that an enterprise that is considered small and medium in one place is seen differently in another. Even within a country, the definition changes over time. Some common indicators employed in the various definitions include total assets, size of labour employed, 
values of annual turnover and capital investment (Baenol, 1994). The small scale industries of Federal Ministry of Industries defined small scale as " enterprises having capital (investment in land, building, machinery and equipment and working capital) up to N60,000.00 and employing not more than 50 person" as far back as 1979. The Central Bank's monetary and credit guidelines, small-scale enterprises were regarded as establishment whose annual turnover is less than N6million and capital not exceeding N10million.

Ayaggari et.al (2003) and Beckley (1988) contends that the "definition of small and medium scale enterprises varies according to context, author and countries". In country such as USA, Britain and Canada small scale business is defined in terms of annual turnover and the number of paid employees. (Ekpeyong and Nyang, 1992) In Britain for example small scale business is conceive as that industry with annual turnover of 2 million pound or less with fewer than 200 paid employees.(Ibid; 4) In the case of Japan it is conceptualized as type of industry, paid up capital and number of employee. Consequently small and medium scale enterprises are defined as those manufacturing with 100million yen paid up capital and 300 employees. Those in wholesale trade with 300million paid up capital with 100 employees while those in retail trade with 100million paid up capital with 50 employees (Fatai, 2012). In the case of Nigeria hardly do you see a clear-cut definition that distinguishes between small and medium scale enterprises. However, the Central Bank of Nigeria in its monetary policies circular No. 22 of 1988 view small scale industry are those enterprises which has annual turnover not exceeding 500,000 naira.(CBN, 2011).

In a more general and comprehensive term Ogechukwu (2006) chronicled a general criteria for defining small and medium scale enterprises in different countries. These includes number of employees, annual turnover, local operations, sales volumes, financial strength, managers and owners autonomy, relatively small markets compared to their industries and capital usually supplied by individual or shareholders etc. As a result of this definitional differences and lack of universal definition, the European Union in 2003 adopted a universally accepted definition of small and medium scale enterprises and micro business as companies with less than 250 employees, with respect to financial criteria, revenues must not exceed 50 million Euro(measure as turn over) or 43million euro(measure as balance sheet) In addition, the European Commission specifies term of ownership stating SMEs must be independent with less than $25 \%$ being owned by outside interest.(European Commission; 2007). In a report of enterprises association, Macqueen (2004) conceive of SMEs as enterprises employing 10-99 full time employees or with a fixed capital investment of US\$1000500,000 .

Small and medium scale enterprises are certainly not transnational company, multinational cooperation, publicly owned enterprises or large facility of any kind. However they can depend on business and ownership structure to become a large business unit (Macqueen 2006) while it can be argued that $80 \%$ of the financing of SMEs come from owners, friends and families, business form can take different form including private ownership, limited partnership, contract and sub-contracts, cooperatives or associations. (Kozak, 2007) Small and medium scale enterprises have a narrow context within which its operation is carried out. However, where it is effectively operated it has capacity to sprout the economic growth and development.

\subsection{Economic Growth}

By the mid-1980s, a group of growth theorists had become increasingly dissatisfied with common accounts of exogenous factors determining long-run growth. They favoured a model that replaced the exogenous growth variable (unexplained technical progress) with a model in which the key determinants of growth were explicit in the model. Consequently, the Endogenous (new) growth concept emerged due to some flaws in the exogenous growth theory and holds that economic growth is primarily the result of endogenous and not external forces (Romer, 1994). Romar endogenous growth concept which was first presented in 1986 takes knowledge as an input in the production function. The theory aimed at explaining the long run growth by endogenizing productivity growth or technical progress. The major assumptions of the theory are: Increasing returns to scale because of positive externalities; Human capital (knowledge, skills and training of individuals) and the production of new technologies are essential for long run growth; Private investment in Research and Development is the most important source of technological progress; Knowledge or technical advances are non-rival good. 
In the New growth concept, the savings rate affects the long run economic growth because in this framework, a higher level of savings and capital formation allows for greater investment in human capital and Research and development. The model predicts that the economy can grow forever as long as it does not run out of new ideas or technological advancement. Just like the exogenous growth theory, the endogenous growth theory professes convergence of nations by diffusion of technology. That is, situation where poor countries manage to catch up with the richer countries by gradual imitation of technology by poorer countries. Romar states that production function of a firm in the following form:

$Y=A(R) f(R i, K i, L i)$ Where:

A - Public stock of knowledge from research and development (R),

$\mathrm{Ri}$ - Stock of results from the stock of expenditure on research and development.

$\mathrm{Ki}$ - Capital stock of firm i

$\mathrm{Li}$ - Labour stock of firm $\mathrm{i}$

The Ri actually represents the technology prevalent at the time in firm i. Any new research technology spill over quickly across the entire nation. Technological progress (advancement) implies the development of new ideas which resemble public goods because they are non-rival. When the new ideas are added as factors of production the returns to scale tend to be increasing. In this model, new technology is the ultimate determinant for long run growth and it is itself determined by investment in research technology. Therefore, Romar takes investment in research technology as endogenous factor in terms of the acquisition of new knowledge by rational profit maximization firms. From the forgoing, we can derive the aggregate production function of the endogenous theory as follow:

$Y=f(A, K, L)$ Where;

$\mathrm{Y}=$ aggregate real output.

$\mathrm{K}=$ stock of capital.

$\mathrm{L}=$ stock of labour.

$\mathrm{A}=$ Technology (or technological advancement).

\subsection{Problems Impeding the Development of SMEs in Nigeria}

SMEs are known worldwide to encounter some structural difficulties, problems or limitations, which if confronted can drive them to promote economic growth and development. Some of the principal problems SMEs face in Nigeria include the following:

\subsection{Inadequate Funding}

It is a known fact internationally that SMEs are funded by their owners' personal or family savings. Nonetheless, the high level of poverty and consequently low level of savings in Nigeria and other Less Developed Countries have made this source of funding for the establishment, growth and development of new and existing SMEs inactively low. This perhaps explains why most SMEs in Nigeria more often than not start off with inadequate funding and afterward start warming up for shut down if external funds from either the government or financial institution do not come. According to Ezeh, 'the unpreparedness of small business owners in terms of capital prior to going into business is said to be accountable for their untimely failure' (Ezeh, 2002). Therefore, most SMEs in Nigeria are not adequately capitalized and as such are not capable to raise funds in the capital market owing to their inability to meet the stipulated strict conditions (i.e. registering as limited liability company) which is regarded as somewhat on the high side (Ireghan, 2009). Inadequate collateral is a key restraint for access to credit in SMEs from banks and other financial institutions. Other factors that hinders SMEs from accessing credits from banks and other established schemes like the SMIEIS, NEPAD, ACA, AGOA etc, include their incapability to raise the necessary equity contribution (a maximum of N500 million exclusive of land and working capital), which is very high. Others include scantily prepared project proposal as well as feasibility study of the project, incomplete and inaccurate financial records and lack of succession plan in event of the entrepreneur's exit (Aremu, 2010). 
Funding is seen by this study as the most hindering factor to the development and sustenance of SMEs towards contributing to Nigeria's economic growth in terms of output of goods and services.

\subsection{Inadequate Infrastructural Facilities}

The problem of unstable and unreliable supply of electricity, dilapidated roads, inadequate supply of water for both home and industrial use, inefficient and costly communication system, among others, have for long hindered the growth and development of SMEs in Nigeria. Nearly all SME operating in Nigeria have one or more power generating plants as an alternative source of power supply. The cost of obtaining, maintaining, sustaining and managing such generating plants are more often than not very expensive and this has made cost of production as well as prices of product very expensive, with the latter turning out to be more and more uncompetitive in comparison with the imported equivalent. It is estimated the cost of providing basic infrastructural amenities at $5 \%$ to $20 \%$ of the total cost of setting up a manufacturing and processing industry in Nigeria (Osoba, 2003). This cost will be significantly higher today taking into account the rapid rate of inflation in the economy.

\subsection{Low Capacity Utilization}

This is perpetually gotten from the low demand for SMEs products owing to their poor quality as well as exorbitant prices. Therefore, sales as well as profits have remained relatively low leading to poor returns on investment. A study of about 39 SME's performance in Nigeria illustrated that a majority of them operated at between 30\%-35\% of their established capacity between 1995-1996 with sales and profit volume showing little increase (NCI, 2001). Erratic supply of power as well as inadequate infrastructural amenities has contributed directly to low capacity utilization of the SMEs in the manufacturing sector in the country.

\subsection{Poor Planning and Management}

Management involves planning, coordination, organization and control of both human and natural resources in an organization to attain its set aims and objectives (Basil, 2005). Therefore, it involves getting things done appropriately and efficiently through people. Nonetheless, a survey of SMEs operating in LDCs showed that owners practically get everything done by themselves without seeking consultation from professionals or experts.

This has resulted to incompetence, inefficiency, wastage and under-utilization of resources available to the organization. In actual fact, planning is the essential function of management (Gold, 2005). Most SME operators venture into business on impulse without adequate feasibility study on the project or business (Mogano, 2001). The problem of poor planning and management in Nigeria's real sector has been traced to inadequate relevant and appropriate information or data relating to the proposed business ventures.

\subsection{Poor Education and Experience}

Closely associated to the problem of planning and management is the low level of education and inadequate business experience among SME operators in Nigeria (Alasan \& Yakubu, 2011). These have given an explanation for the lack of pioneering, inventive, innovative, dynamic, vibrant and entrepreneurial skills and abilities necessary to effectively confront and tackle issues as they emerge. Human resources therefore, constitute the foundation for wealth of nations (Cosson, 2003). According to him, "human resources make up the fundamental basis for the wealth of a nation". Capital and natural resources are inert factors of production, human beings are the active agents who accrue and amass capital, exploit natural and material resources, put up social, economic and political organization and carry forward national development. Without a doubt, a country which is incapable to build and develop the skills and knowledge of its citizens and utilizes them effectively in the economy will not be able to develop anything else. In the view of Essien \&Udofia (2006), effective and successful formal education is the only way to build as well as develop the human skills, expertise and competence required for the growth and development of SMEs in Nigeria and other less developed coutries.

\subsection{Raw Material Management and Choice of Appropriate Technology}

These are fundamental for growing and developing any business, be it large or small. The difficulty relating to small enterprises is the unavailability of quality and superior raw materials as well as its organization at the suitable price and time (Nigerian Economic Summit Group, 2002). In Nigeria, the 
majority of these raw materials are not produced in the country but imported. In addition, a general assessment made about domestic or locally made goods is the non-existence of uniformity and standardization in them. Classification, categorization, cataloging as well as comparison is not feasible or impossible when the quality of the raw materials employed changes from article to article.

The SMEs in agro-allied industries encounter the peculiar difficulty of procurement, maintenance, conservation and storage of materials. Furthermore, the selection of suitable technical knowledge and expertise that would produce superior, quality and standard goods capable of challenging with their international equivalent, as well as meeting both domestic and foreign needs has to be appropriately addressed (Onyinlade, 2005). Most SMEs are confronted with the difficulty of marketing, advertising and selling. Their expansion relies by and large on the size and accessibility of markets for their output. The lack of ability to locate such multi outlets both in the local and international markets is a major setback. The cause for this consist of low standard and poor quality of their output, inadequate marketing skills and techniques resulting from high cost of advertising, promotion, branding, canvassing etc.

\subsection{Inadequate Conducive and Enabling Environment}

The Federal Government fiscal and monetary policies in Nigeria as it relates to business issues have been unpredictable, contradictory, inconsistent and from time to time conflicting (Adebayo, 2003). This has generated a lot of problems for domestic investors as against their foreign participants who have the alternative of making Nigeria a dumping ground for their output. Associated to this is the problem of unlawful taxes (business development tax, business registration tax, business premise tax, sanitation fees, signboard fees, stickers etc) most often than not by state and local government agencies (tax force on this or that). As a result of this, SMEs in Nigeria carry out their operations under high cost and unfavourable business environment.

\subsection{Financial Sector's Efforts towards Promoting SMEs}

The Financial sector in Nigeria is made up of all financial institutions in the economy. The Banker's Committee in Nigeria intervened on 19th June 2001, with a scheme titled the Small and Medium Industries Equity Investment Scheme (SMIEIS). In their view, this was a response to the former president of Nigeria (Olusegun Obansanjo) concern as well as policy measures for the encouragement of small and medium industries as a medium for speedy process of industrialization, sustainable economic growth and development, reduction of poverty and creation of employment. The scheme required all banks operating in Nigeria to save $10 \%$ of their profit before tax (PBT) for equity investment in SMEs.

The scheme goals amongst other includes; helping in the setting up of new feasible SME projects thus accelerating economic growth, development of domestic technology, encourage indigenous entrepreneurship as well as create employment opportunities. The fund will be made accessible for projects in the real sector of the Nigerian economy, which includes agro-allied, information technology and telecommunication, manufacturing, educational establishment, services (directly associated to production in the real sector or to improve production), tourism and leisure, solid mineral, construction and any other activity as maybe determined from time to time by the Banker's Committee.

According to Adebayo (2003), to meet the criteria for the scheme, an enterprise, in addition to being involved in any of the activities listed above, must have a minimum asset base of N200million apart from land and working capital, with the number of staff working for the enterprise not less than 10 and not more than 300 . The enterprise have to be registered as a limited liability company with the Corporate Affairs Commission and act in accordance with all pertinent rules and regulations of the Companies and Allied Matters Act (1990) such as filing of annual reports as well as audited financial accounts. In addition, the enterprise has to act in accordance with all relevant tax laws and regulations and provide returns to the appropriate authorities. Timing of investment exit shall be a minimum of 3 years. Available data as at February 2003 revealed that about 80 banks have put aside N13.07 billion with 28 banks investing around N2.87 billion on 67 investments in 47 Small and Medium Enterprises (Sanusi, 2003). 
Since 2006, more than N43 billion has been put into the scheme, with approximately 10 and 30\% investments (SMEDAN, 2006). In reality, the highest according to the committee is $30 \%$ a trend, which analysts say, goes against the aim for which the scheme was established and quenching the interest the scheme generated initially, when it was introduced. Though, many banks frequently assert to have contributed greatly to the growth and development of the SME sector, a glance into the record illustrates that the severe conditions set by them have made it tremendously difficult for SMEs operators to access funds from them (Inang \& Ukpong, 1992). Aside from Union Bank Plc, which has topped the list of 21 banks with payout of $65.54 \%$ of N3 billion set aside for SMEs in the previous financial year ended March 2005, First bank likewise has disbursed massive funds to SMEs. Most of the other banks have been unwillingly in contributing to the scheme, leading certainly to the future failure of the scheme. From a study carried out on SME operators in Nigeria in 2005, most SME operators are of the same opinion that the major restraint in operating a business in Nigeria is high cost of capital (Oni \& Daniya, 2012). In their view, accessing funds from banks for SME projects is like passing a camel through the eye of a needle, adding that, 'even the so called SMIEIS are just an idle fancy'. Analysts have accused the founding fathers of the project for failure to take into account the cultural nature and environment of the Nigerian society.

The Managing director and Chief Executive Officer of Spring Bank Plc, Mr. Mike Chukwu, said the main problem that has been recognized consisted of environmental, ethnic, cultural and social problems, because the SMIEIS not like most other SME financing arrangements is an equity fund. Adding that, "what the bank is telling the entrepreneurs is: come let our bank join you in owning the company'. A lot of companies that are well established have cultural problems bothering on who owns it. Nigerians like to be the sole owners of their business. Nigerians need to adopt the philosophy of co-ownership. The issue ought to be tackled with continuous education programmes in order to inform the populace about the advantages of co-ownership. Subsequent to the conclusion of the bank consolidation program, a number of banks' chief executives have through their statements been sending misleading signals to SME operators by frequently saying that the emergence of mega banks would not make giving out loans and advances easy, a sign that they do not entirely concur with the goals of SMIEIS. The Banker's Committee ought to look into this issue when they convene their next meeting of stakeholders.

\subsection{Roles of SMEs in Nigeria's Economic Growth and Development}

One expected conclusion that has been drawn on SMEs irrespective of their level of economic activities in the real sub sector is that, if sufficiently financed and developed would bring about rural development as well as economic growth (Oyinlade, 2005). In Nigeria, as in most countries, these roles and functions would not be anticipated to be different noticeably, apart from dissimilarities in their scope as well as input for that matter. This results from the roles given to them (SMEs) by the nation's macroeconomic policymakers, economic planners, and the level to which they are prepared to perform these roles and functions. An unbiased appraisal of the roles of SMEs around the world, though, suffers from insufficient information to precisely do justice to the role they perform in economic growth and development. Nevertheless, some insight on their contributions to economic growth can be gathered from inadequate analytical statistics, findings of previous studies to this effect and authorized journals, periodicals, magazines, newspapers etc. According to a CBN report in 1999, since the 1970s, the Less Developed Countries have shown increased interest in encouraging the growth and development of SMEs for three reasons:

i. The failure of previous industrial policies to create self-sustaining growth.

ii. The increased emphasis on self-reliant method to economic growth and development, which SMEs can promote.

iii. The greater concern to reduce the problems of rural-urban migration, and urban-rural investment disparity.

According to Ogun \&Anyanwu (1999), it is anticipated that the vigorous increment of SMEs would contribute considerably to wide range of growth and development objectives, which comprises of rural development, efficient utilization of local resources, creation of employment, development of domestic technology, mobilization of local funds for investment, human resource development, 
support as well as growth of the functions of local entrepreneurs and equitable distribution of income. It is a known fact that the organization of firms and industries in small and medium scale is a transition stage in a nation's phase of industrialization. That is, an intermediate phase between the prevalence of SMEs to large-scale industries. If this is the case, it must then follow that once a definite stage of industrial growth and development has been attained, the comparative significance of SMEs undertaking would reduce. Nonetheless, SMEs have continued to perform important functions even in the economies of highly industrialized countries and appear to continue doing so. A CBN report in 2006 indicated that development policies which are successful have emphasized the significance of SMEs in universal economic growth and development for the following reasons:

i. To create considerable indigenous entrepreneurship

ii. To ease efficient mobilization of domestic resources such as domestic raw materials, capital, labour and technology.

iii. To decrease regional differences, brain drain, as well as rural-urban migration.

Most of all, it is contended that SMEs growth and development will steer great achievement of economic independence, growth and development with much emphasis in the development of rural areas (Inang \& Ukpong 1992). There is a universal conformity that the usual pattern of growth of many less developed countries in Africa have in previous years resulted in dualistic structure, as macroeconomic policy makers are likely to prefer the urban cities at the cost of the rural areas with resultant outcome of glaring regional differences in the level of income. Most SMEs are expected to be situated in the rural areas where their raw materials are found so that their effective support would act as a measure of industries decentralization, accelerating rural growth and development, steaming urban migration and the resulting difficulties of overcrowding in the cities among others.

A study carried out by Izedomi (2011) on SMEs operations in Nigeria illustrates that greater part of SMEs are found in the commercial cities with service business enterprises and distribution businesses dominating. The prevalence of SMEs in a specific sector of the economy can be as a result of certain factors within that sector.

These factors include:

i. Minimum technology necessary for that enterprise;

ii. Low awareness of managerial knowledge and experience needed by the would be entrepreneur;

iii. Low capital resources needed for establishing such business venture (CBN, 2006).

\section{ConteXtualizing main Sources of Financing SMeS IN Nigeria}

The main sources of business organization cannot be overemphasized. Business finance is however, not easy to come by especially in respect of SME's. Yet, they require funds from every source available to meet their asset needs, for capital expansion. According to Ekpenyong and Nyong (1992), there is wide consensus in Nigeria that government policies are made in favour of the formal sector and against the informal sector. This unfavourable weighs heavily, against the SME's in Nigeria, the formal financial institutions such as commercial banks, merchant banks, development banks and insurance companies and the informal financial institutions consisting of money lender, landlords, and credit and savings cooperative societies, friends and relatives and personal savings.

The commercial banks, merchant banks and development banks provide formal source of finance to SME's but commercial bank is the core of the banking industry. The banks have three social and economic functions: to collect and secure savings and other deposits; to finance the economy by handing out credits; and to facilitate payments and to transfer funds. The financial intermediation role of financial institution has been faulty for anumber of reasons (Aruwa, 2004); inadequacy in building up and securing national savings; bureaucratic obstacles to the financing of small and medium scale enterprises, inability to establish positive relationship between lenders and borrowers; and absence of risk sharing.

Their role is to reduce the gap between supply (the money deposited and potential available) and demand (the money needed for investment) that exists between idle money and productive investment (Gelinas, 1998). Otherwise, the banks offer loans by way of either term loans or an overdraft. An 
overdraft is essentially a short-term finance to meet working capital requirement over a few months and should not be used for a long term investment purpose. According to (Sanusi 2004)a breakdown of the SMIEIS fund investment by sectored distribution, 68.82 percent went to the real sector while service related investment accounted only for 31.18 percent. This he noted is a sharp reversal from the initial trend recorded under the scheme. The bankers committee has allocated the investment of banks with respect to the fund as 60,30 and 10 percent of their funds in core real sector, service related and micro enterprises respectively. Analyzing the geographical spread of the SMIEIS fund, Sanusi (2004) report that Lagos based investments have gulped 56.63 percent of the fund, and Abuja and 18 states receive a balance of 43.47 percent.The point is about the model of growth of SMEs and financing options available, Golis (1998) submit that venture capitalists do not seek enterprises on the start-up and survivor stage but only in the stability and rapid growth rises from venture capitalists. Yet the method of financing remains the critical success factors of SMEs.

\subsection{Financing Options of SMEs in Nigeria}

The major sources of financing SMEs can be classified as debt and equity. The capital structure of a business firm refers to the composition of long-term sources of funds, viz long-term debt-debenture, preference share and equity shares. The finance literature recognizes the importance of equity in business operations.

The existence of high rate of return on investment will make the appeal to take the advantage on lower cost borrowed fund plausible. Thus, external funds are combined with owner's fund to earn much higher rate of return in excess of cost of external fund employed. In this regard, there are two opposing theoretical views and a practical intermediate perspective.

Net income approach accepts that leverage is a significant variable beneficial to an operating business firm, hence may be applied in perpetuity, thus it hypotheses that financial decisions have important effect on the value of the firm. Whereas its opposing school of thought, net operating income approach, assumes cost of equity to increase linearity with leverage, hence financing decision does not matter in the valuation of the firm. This approach is consistent with the popular Modigliani and Miller (MM) perspective. In this respect, it is possible to have either an all-equity-financed firm or alldebt financed business; while the former abounds, the latter is rare in the business world.

The intermediate perspective posited that the cost of capital declines with leverage up to an optimum level at which the value of firm would have been maximized, beyond capital structure schools of thought is the existence of equity (owner's capital) in the play in the financial structure composition. It is widely known that larger firms are to potential financing media than smaller firms that have difficulty marketing long-term equity or debts issues. Thus, size may be important for the following reasons: (i) it determines access to capital market; (ii) it influence firm's credit rating and (iii) it influence the cost at which a firm borrows. In respect of business firms, large firms are properly classified as operating in the formal sector while the informal sector is characterized largely by small scale enterprises.

\subsection{Debt Sources of Finance}

Debt is outside finance (formal and informal) employed in the business with obligation of regular interest payment and retirement of capital when the instrument crystallizes. Formal sources of debt financing of SMEs in Nigeria include the following: loans and advances obtainable on short and medium term bases from banks (commercial and development), national agencies created to aid SMEs such as Export Stimulation Loans (ESL) of the Central Bank of Nigeria, the National Directorate of Employment (NDE), National Poverty Eradication Programme (NAPEP), etc and cooperative credit societies.

The -enterprises are considered more indigenous and informal in their entirety than SMEs and hence may be unable to raise funds from the formal sources. The informal debt sources for SMES are considered more important to this sector than the formal sources which include friends and relations, clubs, esusu and money lenders, which may constitute a major source of more than $60 \%$ of total, owners capital (Ojo, 1995). 


\subsection{Owner's Capital / Equity Sources of Finance}

Owner's investment in the form of capital in the business is the equity. Equity capital can be increased through retention of profit through operation. Equity is important as the take-off capital to meet capital and preoperational expenses. Finance theory argues that borrowed fund is only appropriate for profitably operated businesses with the rate of return on investment higher than the cost of external funds. It is most unexpected that borrowed funds would from the bulk of neither initial capital nor more substantial part of its total capital, thus exposing the business to high financial risk with attendant high interest payments and other attendant strains on the business. Hence, the prevailing situation whereby ownership of capital is very minimal to the requirement of the business, especially industrial based types thereby requiring such enterprises to depend largely on externally sourced fund, is unsatisfied.

Moreover, promoters' problem has been compounded by inability to raise enough external funds, since investors are skeptical of the viability of such businesses, given their high credit risk. However, as SMEs grow and their expansion activities involve the spread of its assets over wider field, its capital requirement may exceed available financial resources of the promoters, then external fund (borrowing) may be a veritable choice. At this developmental stage, the business is able to meet the demand of external fund providers as well as fulfill its expected obligations. As earlier asserted, the altruistic behaviour expected of external fund providers may remain a mirage. Thus reaping the benefits of SMES in developing countries, especially in Nigeria, depends on improving on existing sources or sourcing for alternative equity sources adaptable to the informal "culture".

\subsection{Funds from Specialized Financial Institution}

It is pertinent to recognize government efforts at improving the capital base of SMEs through creation of specialized and developed institutions and specific directives of these and other formal financial institutions, as well as the Central Bank of Nigeria (CBN), targeted towards increased lending to indigenous (SMEs) borrowers. Other efforts are the non-governmental organizations (NGOs) finance supply targeted at the informal sector especially the SMEs sector. The recent government efforts at meeting the needs of the sector include the following:

i. The reconstruction of the former NIDB in the year 2001 to Bank of Industry (BOI) and the merger of Nigerian Bank for Commerce and Industry (NBCI) and the National Economic Reconstruction Fund (NERFUND) with the newly created Bank of Industry.

ii. As part of government efforts at addressing the financing needs of micro entrepreneurs, a microfinance policy was launched by the Federal Government in December, 2005.

iii. The establishment in 2001 of the Small and Medium Enterprises Equity Investment Scheme (SMEEIS) was recognition by government of the need to improve SMEs equity capital. Small and Medium Enterprises Equity Investment Scheme (SMEEIS) was introduced to make access to cheap source of fund possible. It is a fund pooled together by the participating banks with the objectives of:

a) Facilitating the flow of funds for the establishment of new and viable small and medium industrial (SMI) projects;

b) Stimulating economic growth through development of local technology for capable and suitable Nigerians;

c) Generating employment;

d) Eliminating/ reducing the burden of interest and other financial charges for the entrepreneurs;

e) Providing financial, advisory, technical and managerial support;

f) Consulting to the entrepreneurs; and

g) Ensuring output expansion, income redistribution and productivity of intermediate goods meant to strengthen inter and intra-industrial linkages.

The scheme was initiated to provide solution to dearth of long-term finances to SMEs in Nigeria. Through the scheme, banks are expected to jump-start the development of the real sector of the 
economy by financing SMEs excluding trading from equity investment fund pooled from 10 per cent of the profit before tax of commercial banks. The scheme covered enterprises in the following sectorsAgro-allied, information technology and telecommunications, manufacturing, educational, service, tourism, solid minerals and construction. The scheme provides that a firm would be eligible to equity funding by registering with Corporate Affairs Commission, complying with all relevant regulations of the Companies as Allied Matter Act (1990) as well as tax laws and regulation. The participating banks are free to invest the fund in eligible industries in the form of equity investment. Equity investment could be in form of fresh cash injection and/or conversion of existing debts owned to a participating bank. Also, eligible firms could obtain more funds in form of loans from the banks in addition to equity investment outside the scheme arrangement.

\subsection{Finance from Venture Capitalist}

A venture capitalist provides financing for a new business, expansion of existing firm or bail-out for ailing company. Venture capital is some cases involves investment in a company whereby the venture capitalist acquires an agreed proportion of the share capital of the company.

Venture capital is often exposed to high risk as it is not secured and thus exposed to danger of business failure just like other shareholders. A venture capitalist participates in the success of the company through individual and capital gain realized upon selling of his investment or upon gaining floatation on the stock market. An attractive feature for the venture capitalist lies in his right to participate in the management of the project/business and being involved in the company business decision.

Small and Medium Enterprises Equity Investment Scheme (SMEEIS) and venture capital often provide owners with opportunity to exercise redemption right by re-acquiring the shares. Another is through planned or phased exist in the shares. Also, another is via planned or phased exit in tranches over Period of time, or through listing on the exchange. A related financing method is the business angel which is a business mentoring approaching whereby successful business moguls mentor an entrepreneur in business area of interest and experience. In business angels financing, both parties benefit from the arrangement; this is because it allows for the capitalization of the (original) idea or patent, while the capital provider waits until the business is floated on the stock exchange where his reward are reaped in form of capital gain while exit option exit option benefit to the business is exploited.

\section{THEORETICAL FRAMEWORK}

This section, supplies the number of models of economic growth, which are Classical growth model, Solow model, A K model and Schumpeterian growth models.

\subsection{Harrod-Domar Theory of Growth}

Harrod and Domar assign a key role to investment in the process of economic growth. But they lay emphasis on the dual character of investment. Firstly, it creates incomes, and secondly, it augments the productive capacity of the economy by increasing its capital stock. The former may be regarded as the "demand effect" and the latter the "supply effect" of investment. Hence so long as net investment is taking place, real income and output will continue to expand. However, for maintaining a full employment equilibrium level of income from year to year, it is necessary that both real income and output should expand at the same rate at which the productive capacity of the capital stock is expanding. Otherwise, any divergence between the two will lead to excess or idle capacity, thus forcing entrepreneurs to curtail their investment expenditures. Ultimately, it will adversely affect the economy by lowering their incomes and employment in subsequent periods and moving the economy off the equilibrium path of steady growth. Thus, if full employment is to be maintained in the long run, net investment should expand continuously. This further requires continuous growth in real income at a rate sufficient enough to ensure full capacity use of a growing stock of capital. This required rate of income growth may be called the warranted rate of growth or "the full capacity growth rate"

\subsection{The New Growth Theory}

This theory was developed in the 1980's as a response to criticism of the neoclassical growth model. The endogenous growth theory holds that policy measures can have an impact on the long run growth 
rate of an economy. For example a subsidy on research and development or education increases the growth rate in some endogenous growth models by increasing the incentive to innovate. The main implication of recent growth theory is that policies which embrace openness, competition, change and innovation will promote growth. Conversely, policies which have the effect of restricting or slowing change by projecting or favouring particular industries or firms are likely over time to slow growth to the disadvantage of the community.

\subsection{Classical Growth Model}

According to Nellis and Parker (2004), the classical growth model had stemmed from the view of economists of the late 18th century and beginning of the 19th century and mainly linked to the vision and writings of Thomas Malthus. The key point of this theory is having temporary increase of growth rate in terms of countries' production which is achieved as a result of advances in technology. This model supposes that the subsistence level of wages will increase as a result of rise of real GDP per worker. This, one at a time, will result in both the rise of total supply of labour force and demonstration of total population in the country. The real wage will directly decrease with an increase of supply of labour, recurrence real GDP per worker and real income per worker return to the subsistence standard. The fundamental idea of this model is that the effect of economic growth rate originated from capital accumulation and technological change. In contrast, this theory is unsuccessful to explain the fact that new technology and farming techniques will lead to raise in the productivity of agricultural sector. Despite the increase of total population to more than 7 billion, the world has currently an abundant supply of food products.

\subsection{Solow Growth Model}

Solow growth model is thoroughly related to the improvement of the neoclassical growth model by Swan and Solow (1956). According to their contributions, growth is predominantly explicated by the accumulation of labour and physical capital (Neuhaus, 2006). In general, this model concentrates on four variables: capital (K), knowledge (A), output, (Y) and labour (L). Whenever, in any economy, output is produced as a result of combination from some amounts of knowledge, labour and capital. The consideration of this model is that saving rate is most prospective affected by policy. According to Solow model, the division of its incomes between borrowing and taxes and also its taxes behaviours of investment and saving, and the government's purchases division between investment and consumption goods are completely possible to create impact on the saving rate changing. This model further suggests that the economy's balanced growth path changed due to level effect of change in the saving rate. In sum, according to this model, the growth effects obtained only whenever change in the level of technological progress, while all further changes have level effects without growth effect (Romer, 2012).

\subsection{AK Growth Model}

The first wave of endogenous growth model is the AK model. According to the neoclassical growth model, the growth appears exogenously through functions of production. On the contrary, in the AK model, growth rate is supposed to be endogenous. In addition, a fundamental expectation of the endogenous model is that there is long run growth rate positively affected by investment and saving rates (Sørensen \& Whitta-Jacobsen, 2005). This model describes that change in a country's policies, for instance capital investment or subsides to research to have no long run effect but only have level impacts. Furthermore, according to AK model these policies increase the growth rate momentarily, and the growth rate returns in the long run to its original level. On the other hand, this model proposes that there is a positive long run impact on growth rate due to large amount level of investment in defined capital (Li, 2002). According to (McGrattan, 1998) the simple AK model shows the relation between growth rate and investment rates as predicted. In spite of that, simplest versions of this model indicate that there is a positive link between growth rate of output and share investment of output.

\subsection{Schumpeterian Growth Models}

Schumpeterian growth models gather specific kind of economic growth models, which are produced by the endogenous process innovation and introduction of product. The "Schumpeterian growth" term honours the name of Joseph Schumpeter, who defined the progress of capitalism via creative process. Schumpeterian growth models are nearer in essence to Schumpeter's thinking than other those that 
put emphasis on learning by doing, physical capital accumulation and human capital accumulation as foundations of growth process in the economy (Dinopoulos, 2006). The Schumpeterian model of growth has the natural property that neoteric discovery make products obsolete and old technologies. In addition, this creative obliteration lineament in sequence has both normative and positive consequences. On the normative side, in case of development and future research that recent innovation has positive externalities. In case of positive side, it suggests a negative link between future and current body of research, which emerges in the presence of matchless in the likelihood of cyclical patterns of growth and also balances the growth equilibrium (Aghion et al., 1998).

Previous Schumpeterian growth models had analyzed the link between long run growth and trade patterns by using a variety of approaches. They produced product cycle trade that is constructed on the observation which many goods are discovered in the developed countries and their manufacture shifts to developing countries as they are in the low level of technology and they have imitated in this case. Moreover, the determinants of growth rate examined by this model had also analyzed Schumpeterian models in open economies. According to Prior endogenous growth models, there are three comprehensive channels which convey from the impact of openness policy with regard to economic sector to long run growth. First channel is trade, the long run rate of growth and innovation as well as the profitability of $R \& D$ investment increase due to increasing of the size of the market. Secondly, economic openness, through simplifying the information exchange, raises the productivity of researchers and the field of knowledge spillovers. Thirdly, there is the trade openness (Dinopoulos, 2006).

\subsection{Neoclassical Theory}

Following the works of Dinda (2009); Asiedu (2006) and Anyanwu (1998), this study builds on the Neo-classical theory which tends to emphasize the ease of substitution among factors of production (labour, capital, land, and other essentials in the production of commodities), which permits the economy to achieve steady-state growth (a constant proportionate rate of growth of all real variables). Neo-classical theory predicts the long-run equilibrium of a competitive economy, with particular attention paid to the accumulation of capital goods, growth in population and technological progress. Because factor prices are flexible and replaceable among factors possible in such a model, the natural and warranted rates of growth are equal. Dinda (2009) reveals that the endowment of natural resources, openness, macroeconomic risk factors like inflation and exchange rates are significant determinants of investment inflow to Nigeria.

Evidence around the world indicates that small scale enterprises provide an effective means of stimulating indigenous entrepreneurship, enhancing greater employment opportunities per unit of capital invested and aiding the development of local technology (Sule, 1986: World Bank 1995). Through their wide dispersal, they provide an effective means of mitigating rural-urban migration and resource utilization. Furthermore, by producing intermediate products for use in large scale enterprises, SMEs contribute to the strengthening of industrial linkages. These explain the increased interest which developing countries have shown in the promotion SMEs since the 1970s (Ekpenyong and Nyong, 1992)

The impact of all existing credit schemes to SMEs, in terms of providing funds for meaningful and sustained development among the SMEs, had hardly been noticeable. These credit schemes either have a direct or indirect link with banks. The banks by their nature and position in the economy, therefore, remain the known formal source of finance for enterprises (Agumagu, 2006). It is disheartening to know that a 2001 World Bank survey on Nigerian firms showed that although $85 \%$ of the firms had relationships with banks, most of them had no access to their credit. This explains why SMEs in Nigeria represent about $90 \%$ of firms in the Nigerian industrial sector on numerical basis but regrettably contribute as low as one percent to GDP in contrast to countries like Indonesia, Thailand and India where SMEs contribute almost $40 \%$ to GDP (HPACI, 2002). The failure of most of the schemes and the need for a sustainable source of financing SMEs, therefore, necessitated the recent Central Bank of Nigeria (CBN) inspired Banker's Committee initiative which is aimed at committing the banking industry to the provision of finance and other ancillary support to the sub-sector via an equity participation scheme. 


\section{RECOMMENDATIONS}

There is no gain-saying that the Small and Medium Enterprises are a vital force in the industrialization process of developing and emerging economies. Certainly, governments all over the world will continue to accord the sector the high priority it deserves. In order to bring about sustainable development in an environment that is characterized by stiff competition, especially against the backdrop of trade globalization, concerted, coordinated and sustained efforts are required from all operators in the economy, i.e. the government and its agencies/parastatals, NonGovernmental Organizations, relevant financial institutions and international bodies. Accordingly, and with regard to this conceptual articulat6ions, the following are emerging recommendations;

1) There should be diversification of the economy, because our country's economy has over the decades relied heavily on its oil production, we must find ways to diversity our economy and avoid the over reliance on oil. A small and medium enterprise is seen as an essential key if we want our country to achieve its ambition of being an industrialized nation.

2) Government should give more microfinance bank licenses to operate so that they can give loans to the SMEs in Nigeria.

3) Unfriendly business climate should be avoided because Nigeria requires great determination as practicing and potential business owners, microfinance and small and medium enterprises are faced with countless challenges. Nigerian's business climate should be made welcoming to those in the micro, small and medium enterprises because the role played by these small and medium enterprises should not be underestimated since majority of the thriving businesses fall in this category and for us to achieve our goals, adequate attention and support must be directed towards these institutions.

4) Avoidance of failure to adapt to the changing business environment because majority of those who venture into both microfinance and small and medium enterprises are in the business of the money they wants to make. In most cases, such business lack relevant and adequate information about the business they engage. So all these should be avoided by having better thinking mind towards been in business rather than their selfish interest.

5) Policy on Microfinance lending to small and medium enterprises should be encouraged because some microfinance bank do not give loan to the SMEs, so there should be a policy by central Bank of Nigeria mandating the microfinance bank to give loan to the small and medium enterprises in Nigeria.

\section{CONCLUDing REMARKS}

It is no exaggeration to say that despite the lofty objectives of the government in respect of the Small and Medium Enterprises sub-sector, the results are often disappointing and the potentials of small scale industries are not often realized in the industrialization process. This paper highlighted the type of ownership of the SME, the entrepreneur's educational development level; the sub-sector type and the size of the annual revenue of the SME are significant indices and thus affect the financing of the enterprises in Nigeria. Further, the entrepreneur's source of seed capital, source(s) of business/ financial information and the membership of trade/business organization also significantly affect the financing of SMEs. It is obvious that a dynamic SME sub-sector is needed for Nigeria to attain industrialization and sustainable economic development and for its Vision 20-20-20 to be achieved. This subsector is, therefore, vital and imperative for the actualization of Nigeria's vision. The observed weak performance of notable formal financing options, like SMEEIS, occasioned by lingering constraints should, however, be seen as a big challenge for policy makers in the country.

\section{REFERENCES}

[1] Adesaolu,T.O,Oladoyin, A.M\&Oladele,P.O(2005) "A Consideration of the Problems and Prospects of Revitalizing the Small Scale Sector in Nigeria. European Journal of Scientific Research. 7(3), 5-11

[2] Adebayo, J. Y. (2003). Manufacturing Enterprises in Nigeria, Is Finance a constraint to Performance? Journal of Economic Reform, 1(3). 
[3] Adejumo, A.W (2002). The Effect of Government Size on Unemployment rates: Lagos, Foep Publishing Press

[4] Afolabi, M.O. (2013). Growth effect of small and medium enterprises (SMEs) financing in Nigeria. Journal of African Macroeconomics Review, 3 (1): 193-199

[5] Ahiawodzi, A. K. and Adade, T. C. (2012). Access to Credit and Growth of Small and Medium Scale Enterprises in the Ho Municipality of Ghana. British Journal of Economics, Finance and Management Sciences, 6(2): 34 - 51.

[6] Akingunola, R. O. (2015). Small and Medium Scale Enterprises and Economic Growth in Nigeria: An Assessment of Financing Options. Pakistan Journal of Business and Economic Review, 2(1): 78 - 97.

[7] Alasan, S. L., \& Yakubu, A. L. (2011). An Empirical Study of Small Scale Financing in Nigeria. Journal of Unilorin Business School, 1(1), 87-96.

[8] Aremu, M. A. and Adeyemi, S. L. (2011). Small and Medium Scale Enterprises as A Survival Strategy for Employment Generation in Nigeria. Journal of Sustainable Development, 4(1): 200 $-206$.

[9] Aruwa, S.A. (2004). "Financing options for SMEs in Accounting and Research: Department of Accounting, Ahmadu Bello University; Zaria. 1(2).

[10] Ayozie, D. O. and Latinwo, H. K. (2010). Entrepreneurial Developments and Small Scale

[11] Ayyagari M, T. Beck and A. Demirguc-kunt (2003) Small and Medium Enterprises across the Globe. A New database. World Bank, Development Research Group. Working paper 3127 Washington DC

[12] Basil, A. N. O. (2005). Small and Medium Enterprises (SMES) in Nigeria: Problems andProspects. Ph.D. Thesis, St. Clements University.

[13] Beckley, P. (1988). Foreign Direct Investment by Small and Medium Sized Enterprises: The Theoretical Background. Bradford, United Kingdom. University of Bradford Management Centre

[14] Carpenter, R. B. (2001). The Freedom Revolution Washington, D.C: Regnrey Publishing Co.

[15] Central Bank Nigeria (2011). Statistical bulletin, Central Bank of Nigeria, 22(1)

[16] Cosson, M. (2003). The Entrepreneur: An Economic Theory (2nd ed.). Edward Elgar Publishers.

[17] Duro, K (2013). “Multiple Charges Stifle SMEs' Growth”. Nation Newspaper, November18,

[18] Egbuna, C. K. and Agali, I. (2013). Effect of Planning on the Performance of Small and Medium Enterprises in South-Western Nigeria. Asian Journal of Business Management, 5(3): 326 331.

[19] Ekpeyoung, D.B.E. and M.O. Nyoung (1992). "small and medium scale Enterprises Development in Nigeria"; Seminar Paper on Economic Policy Research for Policy Design and Management in Nigeria, NCEMA/AEPC; Nigeria, April.

[20] Essien, P., \&Udofia, A. (2006). Evolving a National Framework for the Emergence of a Strong and Virile Small and Medium Scale Industry Sub-Sector in Nigeria. A Seminar PaperPresented at MAN House.

[21] Evbuomwan G. O., Ikpi A. E., Okoruwa V. O. and Akinyosoye V. O. (2012). Preferences of Micro, Small and Medium Scale Enterprises to Financial Products in Nigeria. Journal ofAgricultural Economics and Development, 1(4): 80-98.

[22] Ezeh, J. A., \&Onodugo, V. A. (2002). Business Policy and Strategic Management: Issues and Trends. Enugu: Kinsmann Publisher Ltd.

[23] Fadahunsi,O., Olu., M., \&Daodu, O (1997)."Promoting Entrepreneurship and Small Business: Lessons of Experiennce" In eds. Small and Medium Enterprises development: Policies, Progrmmes and Prospects. West African Management Development Institutes Network (WAMDEVIN) Pp 129-148earch and Development Institute, Uyo, Nigeria. 1(1) 
[24] Fatai, A.(2012). Small and Medium Scale Enterprises In Nigeria: The Problems And Prospects. Journal of political studies, Department of Political Science, Faculty of Social Sciences Lagos State University. 3(2)

[25] Gelinas, J.B. (1998). Freedom from Debt: The re-appropriation of development through financialself Reliance: University Press, Dhaka-Ottawa.

[26] Gold, S. K. (2005). Entrepreneur's Notebook. Learning Ventures Press.

[27] Golis, C. (1998). Enterprise and Venture Capital: A Business Builder and Investment Handbook, $3^{\text {rd }}$ Edition: Allen and Urwin Business/Finance; Australia. http://dx.doi.org10.4337/9781843765 639

[28] Idowu, F. C. (2013). Impact of Microfinance on Small and Medium-Sized Enterprises in Nigeria. Proceedings of the 7th International Conference on Innovation \& Management, China, $1864-$ 1871.

[29] Inang, E., \&Ukpong, G. (1992). A Review of Small Scale Enterprises Credit Delivery Strategyin Nigeria. CBN Economic and Financial Review, 30(4).

[30] Ireghan, C. (2009). Small Scale Business Development in Nigeria. In Ireghan, C. (Ed.), The Place of Small and Medium Scale Business in the development of a nation State. Nigeria: Lagos, Kaycee Publishers.

[31] Izedomi, A. (2011). Principles of Management. Nigeria: Benin, Alfred-Joe Publishers

[32] Kadiri, I. B. (2012) Small and Medium Scale Enterprises and Employment Generation in Industry Contribution to Nigerian National Development: A Marketing Interface. Information Management and Business Review. 1(2):51-68

[33] Keynes,J.M(1936). The General Theory of Employment, Interest and Money.London: Macmillan for the Royal Economic Society Oluremi, H. SiGbenga, M. (2011). Patterns of Development. London: Oxford University Press.

[34] Kilby, P. (1985). Breaking Entrepreneurial Bottleneck in Less Developed Countries: Is there a Useful Role for Government. Journal of Development Planning, 18 (1).

[35] Kozak, R (2007) Small and Medium Forest Enterprises: Instrument of change in the developing World. Vancouver, British Colombia, University of British Columbia

[36] Lall, S. (1992). "Structural Problems of African Industry" In F.Steward, S.Lall and S.Wnagive (eds): Alternative Development Strategies in Sub-saharaAfrica: Macmillian, London

[37] Mambula, C. (1997). "Factors Influencing the Growth performance and Development of Small Plastic manufacturing Firms (SPMFS) in Nigeria and Implication for Policy". Unpublished Ph.D Dissertation University of wales, Swansea, U.K

[38] Mogano, M. (2001). How to Start and run your own business. Graham and Trotman.

[39] NCI. (2001). The thirteenth meeting of the national council on industry. Nigeria: The Role of Finance. Kuwait Chapter of Arabian Journal of Business and Management Review, 1(9): 79 93.

[40] Nigerian Economic Summit Group. (2002). A Survey of Micro and Small Enterprises. NESG Digest, Lagos.

[41] Obadan, M.I (2003)."Poverty Reduction in Nigeria: The way forward" CBN Economic and Financial review Vol, 39: No 4

[42] Odedokun, M. O. (1998). Effectiveness of Selective Credit Policies Alternative Framework of Evaluation. World Development, 16: 120 - 122.

[43] Ofoegbu, E. O., Akanbi, P. A. \& Joseph, A. I. (2013). Effects of Contextual Factors on the Performance of Small and Medium Scale Enterprises in Nigeria: A Case Study of Ilorin Metropolis. Advances in Management \& Applied Economics, 3(1): 95 - 114.

[44] Ogechukwu, A (2006). The Role of Small Scale Industry in National Development in Nigeria. Texas Corpus Christi, Texas, United State. November 1-3 2006 
[45] Ogun, O., \& Anyanwu, J. C. (1999). Financing Small and Medium Scale Enterprises in Nigeria: Lessons from International Experience. Nigerian Financial Review, 8(1).

[46] Ojo, T.A \& W. Adewunmi (1995). Banking and Finance in Nigeria, United Kingdom: Graham Burn

[47] Onakoya, A. B. O., Fasanya, I. O. \& Abdulrahman, H. D. (2013). Small and Medium Scale Enterprises Financing and Economic Growth in Nigeria. European Journal of Business and Management, 5(4): 130 - 136.

[48] Oni, E. O., \& Daniya, A. A. (2012). Creation of Small and Medium Scale Enterprises in Nigeria:The Entrepreneurial Perspective. International Journal of Management and Administrative Sciences, 1(4).

[49] Onyinlade, A. O. (2005). Effective Financing of Small/Medium Scale Enterprises as an impetusfor poverty alleviation in Nigeria: An analytical approach. International Journal of Economics and Development Issues,51.

[50] Osamwonyi, I.O. \& Tafamel, A.E. (2010). Options for sustaining small and medium scale enterprises in Nigeria: Emphasis on Edo state. International multi-disciplinary Journal of Ethiopia, 4(3): 192-211

[51] Osoba, A. M. (2003). Towards the Development of Small Scale Industries in Nigeria. Nigerian Institute of Social and Economic Research

[52] Sacerdoti, E (2005). Access to Bank credit in Sub-Sahara Africa: Key Issues and ReformStrategies. International Monetary Fund (IMF) Working Paper WP.05? 166.

[53] Sanusi, J. (2004).Research study presentation at the National Summit on Revamping Small and Medium Scale Industries, This day, 10(33)

[54] Sokoto, A. A. and Abdullahi, Y. Z. (2013). Strengthening Small and Medium Enterprises(SMEs) as a Strategy for Poverty Reduction in North Western Nigeria. American Journal of Humanities and Social Sciences, 1(3): 189 - 201.

[55] Terungwa, Azende (2011). An Empirical Evaluation of Small and Medium Enterprises Equity Investment Scheme in Nigeria. Journal of Accounting and Taxation, 3(5): 79-90.

[56] Woldie, A., Leighton, P. and Adesua, A. (2008). Factors Influencing Small and MediumEnterprises (SMEs): An Exploratory Study of Owner/manager and Firm Characteristics.Banks and Bank Systems, 3(3): 5-13.

[57] WorldBank (2010). "Nigeria's Poverty in the Midst of Plenty: The challenge of Growth With inclusion" World bank Papers Washington D.C

\section{AUTHORS' BIOGRAPHY}

Micah Ezekiel Elton Michael is currently rounding up with hisPh.D degree in Forensic Accounting. Micah is a multidisciplinary professional consultant of good repute with over 22 years' experience with a lot of Professional qualifications both national and international professional bodies. He is the Managing Director/CEO at Diamondpearl Consults Limitedand Board Member Saint Monica University Business Consult. Before now, he held positions at MTN Nigeria Communication Limited in charge of Community Relations in Abuja Region, National Permit and Site Sharing Coordinator of MTN Nigeria and was part of the historic team that acquired the highest number of sites for MTNN. His current professional services cover Forensic Accounting Services, Tax Audit, Bank Statement Reconciliation and Educational Research Consultancy Services, and Telecommunication operational services and consultancies in the Telecom sector. He is currently serving as an Advisory Council Member of National Association of Criminology and Security Professional, member Fraud Examiner (ACFE), Austin, USA, Member of the Lagos Chapter of ACFE and a Member of Abuja Chapter Board of the International Institute of Certified Forensic Investigation Professionals (IICFIP).

Kassah virginia is currently rounding up with hisPh.D degreein Management. She is a lecturer in the department of Business Administration in Kaduna State University (KASU), Nigeria. She holds a B.Sc and MBA Business Administration, Ahmad Bello University, Zaria Kaduna State, Nigeria. She has a Post Graduate Diploma in Education from F.C.E Zaria. She also has MSc Business administration from Nasarawa State University Keffi (NSUK), Nigeria and is currently pursuing her $\mathrm{PhD}$ in Management. She presented papers at National and International conferences and seminars. 
She has written many articles which have been published in renowned journals. She has written and published three books on Management. She has served as an external moderator to the federal polytechnic Bids, Niger State, Nigeria. She is a management Consultant.

Ruth A. Andahhas a PhD in Managementdegree from Nasarawa State University Keffi. She is a lecturer in the department of Business Administration, in the faculty of Administration, Nasarawa State University Keffi. She has been teaching for the past nine years. She had her first and second degrees from the University of JOS in 1999 and 2007 respectively.

Citation: MICAH Ezekiel, Elton Micheal et al. "Conceptualizing Small and Medium Scale Enterprises; It'S Implications to the Economic Growth of Nigeria, 1999-2016." International Journal of Managerial Studies and Research, vol 5, no. 8, 2017, pp. 58-76. doi:http://dx.doi.org/10.20431/2349-0349.0508007.

Copyright: (๑) 2017 Authors. This is an open-access article distributed under the terms of the Creative Commons Attribution License, which permits unrestricted use, distribution, and reproduction in any medium, provided the original author and source are credited. 